\title{
Mefenoxam Sensitivity, Aggressiveness, and Identification of Pythium Species Causing Root Rot on Floriculture Crops in North Carolina
}

E. C. Lookabaugh, Department of Plant Pathology, North Carolina State University, Raleigh, NC 27695; K. L. Ivors, Department of Horticulture and Crop Science, California Polytechnic University, San Luis Obispo, CA; and B. B. Shew, Department of Plant Pathology, North Carolina State University, Raleigh, NC 27695

\begin{abstract}
Lookabaugh, E. C., Ivors, K. L., and Shew, B. B. 2015. Mefenoxam sensitivity, aggressiveness, and identification of Pythium species causing root rot on floriculture crops in North Carolina. Plant Dis. 99:1550-1558.

Herbaceous ornamental plants exhibiting symptoms of Pythium root rot were collected from 26 greenhouses in 21 counties in North Carolina (NC) from 2010 to 2012. Plant symptoms ranged from mild stunting to severe wilting, root rot, and death. Roots were plated on selective media, and 356 isolates of Pythium were recovered from 34 host species. Selected isolates were identified by sequencing of the internal transcribed spacer (ITS) rDNA gene region. Seventeen Pythium species were identified, with $P$. aphanidermatum, $P$. irregulare, and $P$. myriotylum comprising $75 \%$ of the 320 isolates sequenced. Twelve of the 26 greenhouses had more than one species present. Mefenoxam sensitivity was tested in vitro by growing isolates in wells of microtiter plates containing clarified V8 agar amended with $100 \mu \mathrm{g}$ a.i./ml

mefenoxam. Colonization was scored after 24 to $48 \mathrm{~h}$ using a scale of 0 (no growth) to 5 (entire well colonized). Fifty-two percent of the isolates were resistant to mefenoxam (mean score $\geq 4$ ). All 32 isolates of $P$. myriotylum were sensitive, whereas sensitivity varied among isolates of $P$. aphanidermatum and $P$. irregulare. Resistant and sensitive isolates of the same species were found within the same greenhouses. The aggressiveness of $P$. aphanidermatum and $P$. irregulare isolates was evaluated on poinsettia, Gerbera daisy, and petunia. $P$. aphanidermatum was more aggressive than $P$. irregulare on poinsettia and petunia; symptoms were mild and no differences in aggressiveness were observed on Gerbera daisy. Sensitivity to mefenoxam was not related to aggressiveness.
\end{abstract}

The greenhouse and nursery industry ranks fourth in all agricultural sales in North Carolina and brings in over $\$ 700$ million annually. Floriculture sales accounted for an estimated wholesale value of $\$ 250.5$ million of this total, placing NC fifth in floricultural production in the United States in 2011 (NCDA, 2012). Major floricultural crops produced in NC include garden chrysanthemum, geranium from cuttings, and poinsettia from cuttings. North Carolina produces more than four million pots of poinsettias annually, with an estimated wholesale value over $\$ 17$ million (NCDA, 2012). Other floricultural crops produced in NC include petunia, Gerbera daisy, snapdragon, various bedding plants, and an array of perennial species. Given the importance of the industry and the diversity of crops grown, it is not surprising that commercially produced ornamentals represent more than $20 \%$ of the samples submitted to the Plant Disease and Insect Clinic (PDIC) at NC State University. Root rots and other diseases caused by Pythium are the most frequently diagnosed problems from floriculture samples submitted to the PDIC (B. Shew, unpublished). However, the extent and severity of diseases caused by Pythium in the NC floriculture industry is not well characterized.

Pythium species are common soilborne plant pathogens that cause stem rots, root rots, and damping off on many ornamental plant species (Martin and Loper 1999). Pythium is a diverse genus comprising at least 106 species (Lévesque and de Cock 2004; Schroeder et al. 2013; Uzuhashi et al. 2010). In general, Pythium spp. are thought of as necrotrophic, opportunistic, nonspecific plant pathogens with broad host ranges, but some species infect only a narrow range of plant hosts. Some species of Pythium are aggressive plant pathogens, whereas others exist mainly as saprophytes or weak root pathogens. Species also vary greatly in their aggressiveness on certain hosts (Abad et al. 1994; Broders et al. 2007; Dorrance et al. 2004;

Corresponding author: E. C. Lookabaugh, Email: eclookab@ncsu.edu

Accepted for publication 7 April 2015.

http://dx.doi.org/10.1094/PDIS-02-15-0232-RE

(C) 2015 The American Phytopathological Society
Higginbotham et al. 2004; Zhang and Yang, 2000; ZitnickAnderson and Nelson 2015). In spite of these differences, most diagnostic clinics, including the PDIC, do not routinely identify Pythium isolates to species because of the time, effort, and skill required to successfully identify and differentiate species based on morphology.

Environmental conditions and common production practices in greenhouses are favorable for the growth and spread of Pythium. Studies conducted in Pennsylvania showed that several species of Pythium can be present in a greenhouse and that a given species can be present on multiple host species within the same greenhouse (Moorman and Kim 2004; Moorman et al. 2002). Pythium populations in greenhouses may also exhibit phenotypic and genotypic changes over time (Al-Sadi et al. 2012). Additionally, Pythium species can have differential sensitivities to certain fungicides, including mefenoxam or metalaxyl (Broders et al. 2007; Moorman and Kim 2004; Moorman et al. 2002; Zitnick-Anderson and Nelson 2015). Resistance to metalaxyl was first reported in Pythium from turf in 1984, after only 3 years of use on the application site (Sanders 1984). Mefenoxam-resistant strains or species of Pythium are now found in many locations and crops, including floriculture crops (Aegerter et al. 2002; Moorman and Kim 2004; Moorman et al. 2002). In spite of these findings, mefenoxam is still widely used throughout the industry due to the limited number of fungicides available for control of Pythium root rot. Treating resistant strains with fungicides containing mefenoxam increases the cost of production without the benefit of reducing disease. Recent research suggests that treating resistant strains with mefenoxam can even stimulate growth of Pythium, resulting in higher rates of damping off in geranium (Garzon et al. 2011). The extent of mefenoxam resistance in populations of Pythium commonly found in floriculture crops in $\mathrm{NC}$ is unknown.

Identifying Pythium isolates to species level is often necessary to determine the potential for plant damage and the likelihood that certain disease control attempts will be successful. Several Pythium species may be recovered from a single plant sample and Pythium is often recovered in combination with other plant pathogens (Zitnick-Anderson and Nelson 2015; B. Shew, unpublished). Difficulty in correctly identifying which species are present on a particular 
sample hinders attempts to attribute a causal agent to a set of symptoms because both pathogenic and saprophytic species of Pythium may be recovered. Differences in pathogenicity and fungicide sensitives among Pythium species complicates development of control strategies. Recently, researchers have developed molecular tools to identify and characterize Pythium species and isolates (Schroeder et al. 2013). These tools could help to improve routine diagnosis and recommendations for control of diseases caused by Pythium in the floriculture industry.

The objectives of this study were to characterize Pythium species associated with important floriculture crops grown in NC and their sensitivity to mefenoxam, and to evaluate the aggressiveness of two predominant Pythium species on three commonly cultivated host plant species.

\section{Materials and Methods}

Sample collection. Herbaceous ornamentals exhibiting symptoms of Pythium root rot were collected from 26 greenhouses in 21 counties in NC. Samples were collected over a period from August 2010 to February 2012. Some greenhouses were selected for sampling based on diagnostic records of Pythium-positive plants submitted through the PDIC. County extension agents identified other sample locations based on histories of disease problems or production of the target crops. In the case of six greenhouses, samples were collected more than once so that spring (for example, petunia) and fall (for example, poinsettia) crops could be sampled from the same greenhouse. The greenhouses sampled varied widely in production systems used, size, and level of management. Growers were asked to provide information on fungicide application practices, irrigation water sources, and sanitation practices. Plant symptoms ranged from slight stunting to severe wilting, root rot, and death. When possible, at least six symptomatic plants were collected from each block. A block consisted of a group of plants of a particular species, cultivar, planting stage, pot size, and/or location within the greenhouse facility. Symptomatic plants were removed from their original pots, bagged, and stored in coolers until processed in the laboratory.

Isolations. Symptomatic roots were selected for direct isolation. Roots were rinsed under running water, blotted dry, and cut into pieces. Three clumps of root pieces, approximately $1 \mathrm{~cm}^{3}$ in volume, were plated on sterile CMA- P $_{5}$ ARP agar (17 g/liter corn meal agar [Becton, Dickinson, and Company] amended with pimaricin, ampicillin, rifampicin [Sigma-Aldrich Co.], and PCNB [Terraclor 75\% WP, Southern Ag Insecticides, Inc.]; Jeffers and Martin, 1986) dispensed in $100 \times 15 \mathrm{~mm}$ Petri plates. Plates were incubated in the dark at room temperature for 24 to $72 \mathrm{~h}$. Colonies resembling Pythium were transferred to fresh CMA-P 5 ARP. After 24 to $48 \mathrm{~h}$, pure cultures were obtained by transferring actively growing hyphal tips onto fresh water agar (18 g/liter Bacto agar [Becton, Dickinson, and Company]) dispensed in $60 \times 15 \mathrm{~mm}$ Petri plates. If bacterial contamination occurred, actively growing hyphal tips were transferred to CMA amended with rose Bengal disodium salt after autoclaving $(0.15$ $\mathrm{g} /$ liter rose Bengal disodium salt [Fisher Scientific, Inc.]). To obtain pure cultures, 5-mm CMA-P ${ }_{5}$ ARP agar plugs were placed on top of the actively growing culture. After $24 \mathrm{~h}$, hyphal tips growing out of the top of the plugs were transferred to fresh water agar plates. Working cultures were maintained on $2 \%$ water agar plates.

For long term storage, cultures were placed into microcentrifuge tubes containing sterile deionized water and hemp seeds. Cultures were also stored in tubes containing only sterile deionized water. Cultures were stored in the dark at $25^{\circ} \mathrm{C}$.

Preliminary morphological identification of isolates. Isolates growing on water agar were transferred to Petri plates containing $0.5 \mathrm{ml} \mathrm{5 \%}$ clarified V8 juice agar (CV8A; $50 \mathrm{ml}$ clarified V8 juice, $15 \mathrm{~g}$ Bacto agar [Becton, Dickinson, and Co.]), $950 \mathrm{ml}$ deionized water, and grass-leaf cultures to observe colony morphology and induce production of sporangia, antheridia, oogonia, and oospores (Abad et al. 1994). Four 5-mm agar plugs were placed in a sterile $60 \times$ $15 \mathrm{~mm}$ Petri plate containing $15 \mathrm{ml}$ of sterile deionized water and 4-cm pieces of autoclaved tall fescue leaves. The grass-leaf cultures were incubated at room temperature under continuous fluorescent light for 3 to 5 days. Species were placed into two groups as having either globose sporangia or filamentous sporangia. These groups were further subdivided by proliferating/nonproliferating sporangia, inflated/noninflated sporangia, oogonia smooth/ornamented, and the presence or absence of hyphal swellings. Pythium species were tentatively identified using keys and descriptions of van der PlaatsNiterick (1981) and Abad et al. (unpublished data).

Identification of Pythium species with ITS sequencing. The internal transcribed spacer region (ITS1-5.8S-ITS2) of the rDNA gene of the isolates was sequenced for DNA-based identification. Isolates were grown on potato dextrose agar (PDA; 35 g/liter PDA [Becton, Dickinson, and Company]) for 7 to 10 days at room temperature (20 to $25^{\circ} \mathrm{C}$ ). Mycelium mats were stripped from the agar surface, placed in a $1.5-\mathrm{ml}$ microcentrifuge tube, and stored at $-20^{\circ} \mathrm{C}$. Genomic DNA was extracted from mycelia with the PUREGENE DNA Isolation Kit for 10 to $20 \mathrm{mg}$ of tissue (Qiagen, Valencia, CA) with a protocol optimized for Pythium and Phytophthora (K. L. Ivors, unpublished data).

PCR amplification of the ITS region was performed using ITS4 $\left(5^{\prime}\right.$ TCCTCCGCTTATTGATATGC) and ITS5 (5' GGAAGTAAAA GTCGTAACAAGG) primers (White et al. 1990). Reactions were $25 \mu \mathrm{l}$ in volume and composed of $5.0 \mu \mathrm{l}$ of $5 \times$ GoTaq Colorless Flexi Buffer (Promega Corporation, Madison, WI), $1.5 \mu \mathrm{l}$ of $25 \mathrm{mM}$ $\mathrm{MgCl}_{2}, 2.5 \mu \mathrm{l}$ of $40 \mathrm{mM}$ dNTP mix $(10 \mathrm{mM}$ of each dNTP; Promega Corporation), $0.25 \mu \mathrm{l}$ of each $50 \mu \mathrm{M}$ primer, $0.25 \mu \mathrm{l}$ of GoTaq DNA polymerase ( $5 \mathrm{U} / \mu \mathrm{l}$; Promega Corporation), $14.25 \mu \mathrm{l}$ nuclease-free water, and $1 \mu \mathrm{l}$ of $1-\mathrm{ng} / \mu \mathrm{l}$ extracted DNA. Thermal cycling conditions consisted of an initial denaturation step of $95^{\circ} \mathrm{C}$ for $4 \mathrm{~min} ; 35$ cycles of $95^{\circ} \mathrm{C}$ for $30 \mathrm{~s}, 55^{\circ} \mathrm{C}$ for $30 \mathrm{~s}$, and $72^{\circ} \mathrm{C}$ for $1 \mathrm{~min}$; and a final extension step of $72^{\circ} \mathrm{C}$ for $10 \mathrm{~min}$. PCR products were purified with USB ExoSAP-IT PCR Product Cleanup (Affymetrix) and submitted to ETON Bioscience, Inc. for sequencing. DNA sequences were aligned and manually edited with CLC Main Workbench 6 (CLC Bio). In a few cases, mixed sequences were suspected. In that event, the cultures were hyphal-tipped and retransferred. DNA was extracted from pure cultures and PCR repeated to obtain clean sequence data. Edited sequences of each isolate were compared with sequences in the nonredundant nucleotide database GenBank available through the National Center for Biotechnology Information using the BLAST algorithm (Altschul et al. 1997). The BLAST parameters for the sequences were e-values, maximum identity match, and query coverage. Identities were selected based on e-values of 0.0 , maximum identity match of $98 \%$ or greater, and a query coverage of $98 \%$ or greater (Table 1).

Mefenoxam sensitivity of Pythium isolates. Individual isolates were screened for mefenoxam sensitivity using an assay previously developed for Phytophthora spp. (S. N. Jeffers, Clemson University, personal communication) and modified for use with Pythium. The assay was conducted in 48-well microtiter plates (Olson et al. 2013). The wells were $10 \mathrm{~mm}$ in diameter and arranged in eight columns $\times$ six rows (VWR International, Inc.). Three rows of wells contained $0.5 \mathrm{ml} 5 \% \mathrm{CV} 8 \mathrm{~A}$ and three rows contained CV8A amended with $100 \mu \mathrm{g}$ a.i./ml mefenoxam (trade name Subdue Maxx, Syngenta Crop Protection). Previous experiments established $100 \mu \mathrm{g}$ a.i. $/ \mathrm{ml}$ as a discriminatory dose for mefenoxam sensitivity (Moorman et al. 2002; E. Lookabaugh, unpublished data).

To obtain actively growing cultures, isolates were transferred to $60 \times 15 \mathrm{~mm}$ Petri plates containing $5 \mathrm{ml} \mathrm{5 \%} \mathrm{CV8A}$ and incubated in the dark at $25^{\circ} \mathrm{C}$ for $24 \mathrm{~h}$. Six $1-\mathrm{mm}$ plugs were cut from the advancing edge of the actively growing colony with a sterilized glass Pasteur pipet. One plug was transferred into the center of six wells of a freshly prepared test plate with the aid of a flame-sterilized hypodermic needle. Plates were incubated in the dark at $25^{\circ} \mathrm{C}$ for $48 \mathrm{~h}$ or until mycelium in the control wells completely covered the agar surface. Each plate screened eight isolates (one isolate per column) with three observations in amended media and three observations in nonamended media.

Colonization was scored on a rating scale in which $0=$ no growth, $1=\mathrm{a}$ few hyphae growing from plug but only visible microscopically, 2 = hyphae growing uniformly around plug but visible only 
microscopically, 3 = hyphae growing uniformly around plug and just visible macroscopically, $4=$ hyphae visible macroscopically but not completely covering agar surface, and $5=$ agar surface completely covered by mycelium and growth equal to that in nonamended wells (Olson et al. 2013). Isolates with mean sensitivity scores of 4 were considered resistant to mefenoxam (Fig. 1). Each round of testing included a known mefenoxam-resistant isolate of Pythium aphanidermatum and a known mefenoxam-sensitive isolate of $P$. aphanidermatum obtained from G. W. Moorman at Pennsylvania State University. The entire procedure was completed twice for each isolate.

Pathogenicity and aggressiveness of $P$. aphanidermatum and $P$. irregulare on selected hosts. Pathogenicity and aggressiveness of $P$. aphanidermatum and $P$. irregulare were evaluated on three herbaceous ornamental plant species commonly grown in NC greenhouses. Seeds of petunia (Petunia $\times$ hybrida) 'Pretty Grand White' were obtained from Ball Seed Company, Inc. Rooted cuttings of Gerbera daisy (Gerbera jamesonii) 'Jaguar Yellow' (trial 1) and 'Jaguar Orange Picotee' (trial 2) were provided by Green Circle Growers. Roots from selected cuttings from each source used in the trials were plated on CMA-P 5 ARP media to verify clean starting material. Cuttings of poinsettia (Euphorbia pulcherima) 'Angelica White' were taken from stock plants maintained by D. M. Benson (NCSU, Raleigh, NC). To produce rooted plugs of petunia, seeds were sown into new 80-cell plug trays containing Fafard 2 peat-based potting mix (Conrad Fafard Inc.). Trays were maintained on a mist bench until roots completely colonized the cell and white roots began to grow out of the drainage hole. The mist system cycled on for $1 \mathrm{~min}$ six times daily. To produce rooted cuttings of poinsettia, terminal cuttings (approx. $10 \mathrm{~cm}$ long, two to four leaves per cutting) were taken with a flamed scalpel. Cuttings were placed in Oasis Wedge growing media (Smithers-Oasis North America) and maintained under mist irrigation until roots began to grow out of the bottom of the foam wedge. Rooted plugs of petunia and Gerbera daisy were transferred to new $10-\mathrm{cm}$ plastic pots containing Fafard $4 \mathrm{P}$ peat-based potting mix. Rooted plugs of poinsettia were transferred to new $15-\mathrm{cm}$ plastic pots containing Fafard 4P peat-based potting mix. Once transplanted, the plants were fertilized with $5 \mathrm{~g}$ of Osmocote 19-6-12 (Scotts) sprinkled evenly on the pot surface and watered in. Plants were hand-watered twice a day for the duration of the trial. To control whiteflies, poinsettia and petunia plants were treated with Marathon $15 \mathrm{G}$ (OHP, Inc.) insecticide; $1 \mathrm{~g} / 10$-cm pot, $1.4 \mathrm{~g} / 15$-cm pot, prior to inoculation.

Six isolates of $P$. aphanidermatum and six isolates of $P$. irregulare were selected from the isolate collection obtained as described above.
The isolates of $P$. aphanidermatum were originally obtained from poinsettia and isolates of $P$. irregulare were originally obtained from Gerbera daisy, petunia, and snapdragon. The six isolates of each species included three isolates resistant to mefenoxam and three isolates sensitive to mefenoxam as determined above. Inoculum was prepared by transferring four 4-mm-diameter agar disks from an actively growing culture into $125-\mathrm{ml}$ flasks of twice-autoclaved long-grain rice $(25 \mathrm{~g}$ rice and $18 \mathrm{ml}$ deionized water) and cultures were incubated for 5 days at $25^{\circ} \mathrm{C}$ (Holmes and Benson 1994). Flasks were shaken twice daily to promote uniform colonization of rice grains and prevent clumping.

Petunia and Gerbera daisy growing in $10-\mathrm{cm}$ pots were inoculated by placing three colonized rice grains of the test isolate evenly in the potting media around the plant base $(1 \mathrm{~cm}$ deep and $2.5 \mathrm{~cm}$ from the stem). Poinsettias growing in $15-\mathrm{cm}$ pots received six rice grains per pot to account for the larger volume of the pots. Saucers were placed under the pots for $48 \mathrm{~h}$ post inoculation and then removed for the duration of the trial. Noninoculated plants of each host were included as controls. The experiment was arranged in a split-plot design with four randomized blocks of the three plant species as whole plots and the 12 isolates as the subplots. Trial 1 of this experiment was conducted in July 2012 and trial 2 was conducted in December 2012. The average temperature throughout the duration of trial 1 was $26^{\circ} \mathrm{C}$ (21 to $42^{\circ} \mathrm{C}$ ). The average temperature throughout the duration of trial 2 was $24^{\circ} \mathrm{C}\left(16\right.$ to $\left.31^{\circ} \mathrm{C}\right)$.

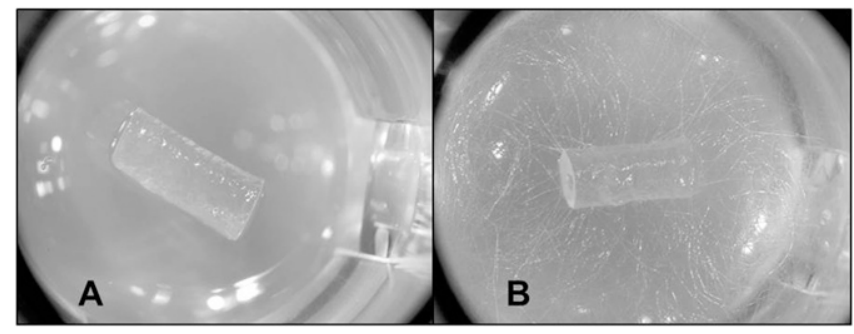

Fig. 1. Rapid mefenoxam sensitivity assay showing: $\mathbf{A}$, rating $=0$, no growth (sensitive) and $\mathbf{B}$, rating $=5$, agar surface completely covered by mycelium and growth equal to that in nonamended wells (resistant). Ratings not shown were $1=a$ few hyphae growing from plug but only visible microscopically, 2 = hyphae growing uniformly around plug but visible only microscopically, $3=$ hyphae growing uniformly around plug and just visible macroscopically, 4 = hyphae visible macroscopically but not completely covering agar surface. Isolates with mean sensitivity scores $\geq 4$ were considered resistant to mefenoxam.

Table 1. Species of Pythium isolated from floriculture crops grown in 26 greenhouses in North Carolina from 2010 to 2012

\begin{tabular}{|c|c|c|}
\hline Species & Percentage of isolates ${ }^{y}$ & Reference accessions $^{\mathbf{z}}$ \\
\hline Pythium irregulare & 39 & $\begin{array}{l}\text { HQ643646.1 (84); HQ643595.1 (14); JN630483.1 (7); HQ643600.1 (6); HQ643642.1 (4); HQ643650.1 } \\
\text { (3); AY598702.2 (2); HQ643636.1 (2); JN630488.1, HQ643647.1, HQ643601.1, GQ410393.1, } \\
\text { JN630481.1 (1 each); }\end{array}$ \\
\hline P. aphanidermatum & 25 & AY598622.2 (76); KF840479.1 (2); JN695786.1, DQ059572.1, JQ898455.1 (1 each) \\
\hline P. myriotylum & 10 & HQ237488.1 (22); HQ643702.1 (9); HQ643703.1 (1) \\
\hline P. dissotocum & 10 & AY598634.2 (24); KC689901.1 (4); KC689900.1 (3) \\
\hline Pythium sp. & 6 & No match (19) \\
\hline P. segnitium & 4 & HQ643772.1 (12) \\
\hline P. catenulatum & 1 & HQ643494.1 (3); HQ237487.1 (1) \\
\hline P. rostratifingens & 1 & JN630500.1(2); FJ415927.1 (1) \\
\hline P. mamillatum & $<1$ & HQ643688.1 (2) \\
\hline P. helicoides & $<1$ & AY598665.2 (2) \\
\hline P. inflatum & $<1$ & AY598626.2 (1) \\
\hline P. intermedium & $<1$ & HQ643577.1 (1) \\
\hline P. chamaehyphon & $<1$ & AY598666.2 (1) \\
\hline P. litorale & $<1$ & JX985744.1 (1) \\
\hline P. splendens & $<1$ & GU983648.1 (1) \\
\hline P. ultimum & $<1$ & KC689906.1 (1) \\
\hline P. vexans & $<1$ & GU133578.1 (1) \\
\hline
\end{tabular}

y Percentage of the 320 isolates identified to species by sequencing the internal transcribed spacer (ITS1-5.8S-ITS2) region of nuclear rDNA.

${ }^{\mathrm{z}}$ GenBank accession number for closest match based on $>98 \%$ sequence homology. The number of isolates matching the accession is indicated in parentheses. 
Plants were monitored weekly for the development of aboveground symptoms (wilting, stunting, chlorosis) of Pythium root rot. Poinsettia plant heights were recorded at day zero (day of inoculation) and once a week for the remainder of the trial. Heights (from plant base to shoot apex) were measured with a ruler to the nearest centimeter. Plants were maintained in the greenhouse until no new plants developed above-ground symptoms (48 days for trial 1 and 63 days for trial 2). At the end of the experiment, above-ground symptoms were evaluated on a visual scale of $1=$ healthy; $2=$ slightly stunted; 3 = chlorosis, moderate stunting and/or defoliation; 4 = wilting and/or severe stunting; $5=$ dead. Plants were carefully inverted, the pot was removed, and the roots were observed with the growth media intact. Visual root rot ratings were assessed based on the size and integrity of the root ball and root color. The rating scale used was $1=$ healthy white roots with root ball completely intact; $2=25 \%$ root rot, some root discoloration present; $3=50 \%$ root rot, brown discoloration evident throughout root system, root ball integrity fairly weak, root cortex sloughs off easily; $4=75 \%$ root rot, brown dead roots evident throughout root system, root ball integrity severely compromised, very few white roots; $5=100 \%$ brown dead roots, root ball lost all integrity. The tops of the plants were cut from the roots at the soil line and fresh weights were taken to the nearest gram.

Each plant was assayed for the presence of Pythium in the roots. Roots were rinsed with running water blotted dry, and plated on CMA- $\mathrm{P}_{5} \mathrm{ARP}$ media as previously described. Plates were incubated in the dark at room temperature for 24 to $48 \mathrm{~h}$. Noninoculated control plants were also assayed. Recovered isolates were transferred to water agar and observed. After incubation, isolates were tentatively identified as $P$. aphanidermatum or $P$. irregulare and then grown in grass-blade culture to confirm the species based on morphological characteristics. Isolates were then rescreened for mefenoxam sensitivity as described above.

Isolate aggressiveness on poinsettia, Gerbera daisy, and petunia was evaluated based on root rot ratings, above-ground symptom ratings, and final top weight measurements. The difference in initial and final plant height measurements was also used to evaluate aggressiveness on poinsettia. Two plants were lost during the trial and their corresponding data points were removed from the data before analysis. Data from both trials were combined and isolate effects on root rot and above-ground symptom ratings were analyzed with PROC Glimmix (SAS 9.3; SAS Institute). Host, isolate, and the interaction were treated as fixed effects and trial and rep were treated as random effects. The host by isolate interaction was significant; therefore, the least-squares means were calculated for the interactions and the simple effects of isolates were analyzed within host to determine significant differences $(P \leq 0.05)$. Single-degree-of-freedom linear contrasts were performed to compare aggressiveness of species and mefenoxam-resistant and -sensitive isolates.

Isolate effects on top weight measurements were analyzed with PROC Glimmix. Due to inherent differences between host sizes, data were sorted by host before further analysis as described above.

\section{Results}

Sample collection. A total of 356 isolates of Pythium were recovered from 36 plant species and one or more isolates of Pythium were recovered from plants collected in 26 of the 28 greenhouses sampled. Pythium was recovered most often from poinsettia (Euphorbia pulcherrima), garden mum (Chrysanthemum spp.), snapdragon (Antirrhinum majus), lantana (Lantana spp.), petunia (Petunia spp.), and Gerbera daisy (Gerbera spp.) (Fig. 2). A range of apparent disease incidence was observed across greenhouses, with some greenhouses having only rare and scattered symptomatic plants, and others having widespread outbreaks of plants with root rot symptoms. The plants sampled expressed a range of symptoms from slight stunting to severe wilting, root rot, and death. The most severe symptoms were seen on poinsettia, garden mum, Gerbera daisy, and snapdragon. The most common symptoms observed on poinsettia were severe root rot, root sloughing, upward cupping of the foliage, wilting, stem lesions, severe stunting, and death. Symptoms associated with
Gerbera daisy included root discoloration, root sloughing, wilting, stunting, and delayed flower development. On garden mum, Pythium was often isolated from plants coinfected with Fusarium oxysporum or those infested with insects (including cutworms, army worms, and noctuid moths), with severe root rot and wilting observed. In
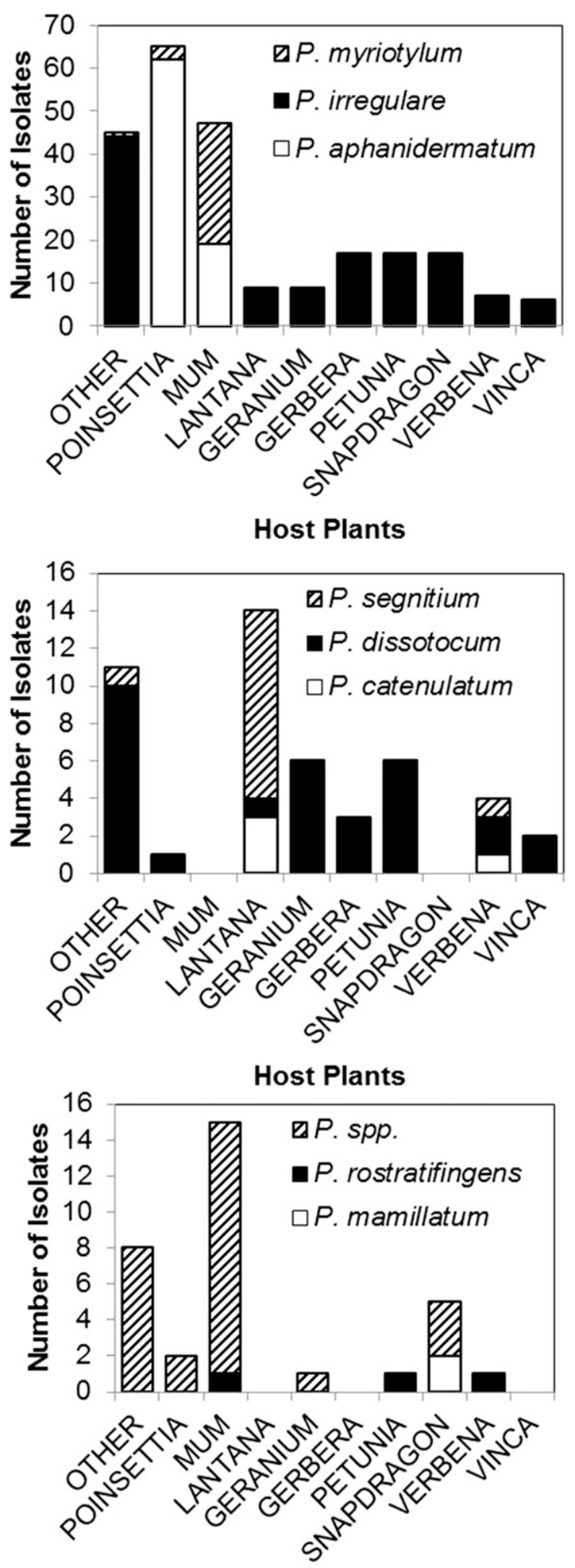

Host Plants

Fig. 2. Diversity of Pythium species isolated from hosts sampled from North Carolina greenhouses. Shading patterns represent different Pythium species as indicated in the legend. Pythium spp. includes 9 genotypes of 8 species and 19 isolates that could not be identified to species. 
contrast, symptoms on petunia were mild, with minor stunting the only symptom observed. Infected roots appeared white and healthy. On snapdragon, the most common symptoms were wilting and root discoloration, whereas on Fuchsia, delayed flowering and stunting were observed. On other bedding plants (Vinca and pansy), the most common symptoms were root discoloration and stunting.

Seventeen species of Pythium were identified from sequencing 320 of the 356 isolates collected (Table 1). Thirty-six isolates were lost due to bacterial contamination. $P$. myriotylum, $P$. aphanidermatum, and $P$. irregulare comprised $75 \%$ of the isolates sequenced. Nineteen isolates, putatively identified as Pythium sp., did not match any sequences listed in GenBank and could not be identified based on morphological characteristics. P. irregulare was recovered from plants in greenhouses at 14 locations, $P$. aphanidermatum at 10 , and $P$. myriotylum at 5. Plants from 12 locations had more than one species present. In general, there was not a strong association of a given Pythium species with a particular greenhouse, with the exception of one greenhouse, in which $P$. irregulare comprised $94 \%$ of all isolates collected. Multiple species of Pythium were recovered from 13 host species. Pythium species were not associated with any particular host species with the exception of poinsettia, in which $P$. aphanidermatum comprised $91 \%$ of the isolates from this host (Fig. 2). P. aphanidermatum was recovered only from poinsettia and garden mum. Among other frequently isolated species, $P$. myriotylum was recovered from poinsettia, garden mum, and fairy fanflower (Scaevola aemula) and P. irregulare was recovered from 19 hosts, including petunia, snapdragon, Gerbera daisy, and geranium (Pelargonium spp., Fig. 2).

Mefenoxam sensitivity. Mefenoxam sensitivity ratings for individual isolates were highly consistent within samples and across trials, with isolates scoring either 0 (no growth) or 5 (mycelium completely covering the well) in all cases. Of the 356 isolates tested, $52 \%$ were resistant to mefenoxam at $100 \mu \mathrm{g}$ a.i./ml (more than 5 times the label rate of $17 \mu \mathrm{g}$ a.i./ml Subdue Maxx). Both resistant and sensitive isolates were recovered from plants collected from 12 greenhouses and 12 host plants, although the frequencies varied among hosts (Fig. 3). All 20 isolates from Gerbera daisy were resistant to mefenoxam regardless of the greenhouse sampled, whereas 99\% of isolates from garden mum were sensitive to mefenoxam. In addition, resistant and sensitive strains of the same Pythium species were found within the same greenhouse. Sensitivity to mefenoxam varied within isolates of $P$. aphanidermatum and $P$. irregulare, whereas all 32 isolates of $P$. myriotylum were sensitive to mefenoxam (Table 2). Two additional species ( $P$. catenulatum and $P$. dissotocum) had both resistant and sensitive isolates. Both isolates of $P$. mamillatum obtained in the survey were sensitive to mefenoxam. All 12 isolates of $P$. segnitium and all three isolates of $P$. rostratifingens were resistant to mefenoxam (Table 2).

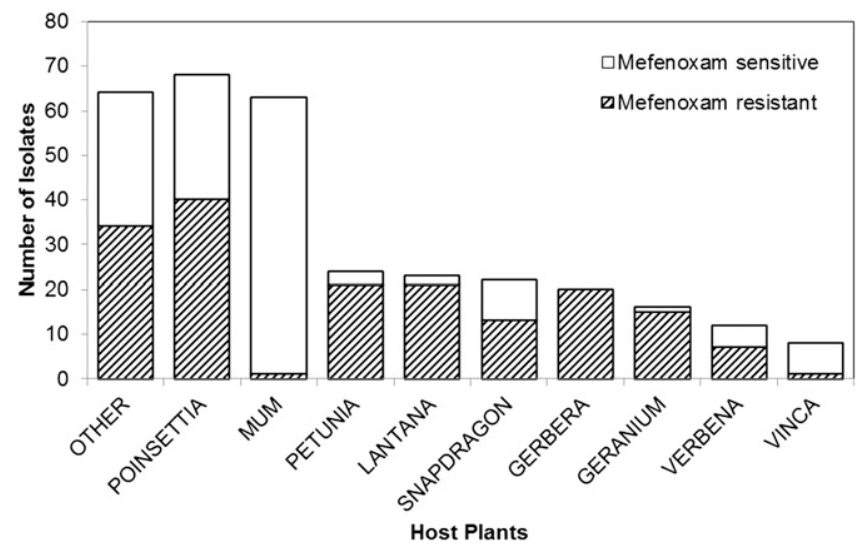

Fig. 3. Mefenoxam resistance of Pythium species grouped by host species of isolation. Shaded bars represent isolates resistant to mefenoxam at $100 \mu \mathrm{g}$ a.i. $/ \mathrm{ml}$ and white bars represent sensitive isolates.
Pathogenicity and aggressiveness. $P$. aphanidermatum and $P$. irregulare were used for pathogenicity and aggressiveness trials because these were identified as the predominant Pythium species in North Carolina greenhouses. Poinsettia and petunia were selected as hosts because of their economic importance to North Carolina greenhouses and their differences in symptom expression of infected plants. A severe root rot epidemic occurred on Gerbera daisy in one greenhouse in 2011 and the causal agent was identified as $P$. irregulare. Gerbera daisy was selected as the third host for pathogenicity and aggressiveness trials in response to this outbreak. Inoculations resulted in production of Pythium root rot symptoms in both trials, with disease, as indicated by root rot rating, above-ground symptom rating, top weight, and plant height, being more severe in trial 1 than in trial 2. However, results were consistent across trials and data were combined for analysis and presentation. In both trials, poinsettia expressed more severe symptoms than Gerbera daisy or petunia. Typical symptoms observed on poinsettia included stunting, downward cupping of the leaves, wilting, defoliation, root discoloration, severe root rot, and in some cases, complete loss of root ball integrity. On Gerbera daisy, symptoms included delayed flowering, minor stunting, root discoloration, and root rot. Inoculated petunia plants were difficult to distinguish from noninoculated control plants based on above-ground symptoms. Root rot was less pronounced than in Gerbera daisy and poinsettia. Symptoms included root sloughing and minor reductions in root ball integrity relative to noninoculated controls. Root discoloration was not a common symptom in petunia and most of the root systems remained white in color. In all hosts, isolations from inoculated plants always yielded the inoculated Pythium species. Pythium was never recovered from noninoculated control plants.

Root rot ratings. Averaged across isolates and species, the three hosts tested did not differ in root rot rating $(P=0.2380)$; however, host response depended on the isolate as indicated by a significant isolate by host interaction $(P=0.0082)$. Linear contrasts indicated that $P$. aphanidermatum caused more severe root rot symptoms (mean rating of 2.5) than $P$. irregulare (mean rating of $2.0 ; P=$ 0.0008 ), but there was no difference in root rot ratings in plants inoculated with mefenoxam sensitive compared with resistant isolates (2.3 versus $2.2, P=0.2770$; Table 3 ). When inoculated with $P$. aphanidermatum, poinsettia had a mean root rot rating of 3.5 , whereas mean ratings were 2.0 on petunia and 2.1 on Gerbera daisy (Table 4). Isolate PAS2, a mefenoxam sensitive isolate of P. aphanidermatum, was the most aggressive isolate on poinsettia, causing an average root rot rating of 4.1 (Table 4). Root rot also was greater on poinsettia inoculated with $P$. aphanidermatum isolates PAS1 (sensitive), PAS3 (sensitive), and PAR4 (resistant) than on the noninoculated control. P. aphanidermatum isolate PAR6 (resistant) was the most aggressive on petunia as measured by root rot rating, with an average rating of 2.4 (Table 4). Within Gerbera daisy, inoculation with $P$. aphanidermatum isolate PAS1 (sensitive) and $P$. irregulare isolate PIR12 (resistant) resulted in the highest root rot ratings, with an average rating of 2.5 for each; no other isolates caused significant

Table 2. Prevalence of resistance to mefenoxam in populations of Pythium recovered from roots of floriculture crops grown in 26 greenhouses in North Carolina from 2010 to 2012

\begin{tabular}{lcc}
\hline Species & $\begin{array}{c}\text { Number of } \\
\text { isolates }\end{array}$ & $\begin{array}{c}\text { Mefenoxam resistant } \\
\text { isolates }(\boldsymbol{\%})^{\mathbf{z}}\end{array}$ \\
\hline Pythium irregulare & 127 & 70 \\
P. aphanidermatum & 81 & 46 \\
P. myriotylum & 32 & 0 \\
P. dissotocum & 31 & 84 \\
P. segnitium & 12 & 100 \\
P. catenulatum & 4 & 25 \\
P. rostratifingens & 3 & 100 \\
P. mamillatum & 2 & 0
\end{tabular}

${ }^{\mathrm{z}}$ Resistant to mefenoxam (Subdue Maxx; Syngenta Crop Protection) at 100 $\mu \mathrm{g}$ a.i./ml. 
root rot on Gerbera daisy relative to the control. Except in the case of PIR12 on Gerbera daisy, none of the isolates of $P$. irregulare caused levels of root rot that could be distinguished from the noninoculated control. Linear contrasts within hosts indicated that isolates of $P$. aphanidermatum caused more root rot than isolates of $P$. irregulare on petunia and poinsettia, but not Gerbera daisy (Table 5).

Above-ground symptom ratings. Averaged across isolates, the three hosts tested did not differ in expression of above-ground symptoms $(P=0.3602)$; however, host response depended on the isolate as indicated by a significant isolate by host interaction $(P=0.0024)$. The interaction was attributed to differences in isolate aggressiveness on poinsettia (Table 6). Linear contrasts indicated that $P$. aphanidermatum caused more severe above-ground symptoms than $P$. irregulare $(P=0.0022)$, but there was no difference between plants inoculated with sensitive compared with resistant isolates $(P=$ 0.3651; Table 3). Isolates PAS1 and PAS2 ( $P$. aphanidermatum; mefenoxam sensitive) resulted in the most severe above-ground symptoms on poinsettia (Table 6). Above-ground symptoms often were very mild and ratings did not differ among isolates inoculated on petunia or Gerbera daisy. Linear contrasts of ratings indicated that $P$. aphanidermatum caused more severe above-ground symptoms on petunia and poinsettia than P. irregulare (Table 5).

Differences in top weights. Averaged across isolates, hosts responded differently to isolate grouped by species and mefenoxam sensitivity (Table 5). Average top weights of petunia inoculated with
$P$. aphanidermatum were $36.1 \mathrm{~g}$ compared with $41.6 \mathrm{~g}$ on plants inoculated with $P$. irregulare $(P=0.0028$; Table 5$)$. On poinsettia, inoculation with $P$. aphanidermatum resulted in lower top weights than inoculation with $P$. irregulare $(P=0.0442)$ and inoculation with sensitive isolates resulted in lower top weights than with resistant isolates $(P=0.0093$; Table 5). There were no effects of isolate species or mefenoxam sensitivity on Gerbera daisy.

\section{Discussion}

Composition and diversity of Pythium spp. varied within and among hosts and greenhouses sampled in North Carolina. Greenhouse populations in NC were highly diverse; 17 species were identified in this study. An additional 19 isolates, putatively identified as Pythium sp., did not match any sequences listed in GenBank based on the criteria we used and some may represent additional diversity if they belong to currently unknown species. The presence of two or more Pythium spp. in many greenhouses probably indicates multiple sources of inoculum. A variety of problems with production practices were observed in some greenhouses. Poor sanitation, particularly between crops, and poor choice/rotation of fungicides were the most common problems. Both could have increased the likelihood of multiple introductions and persistence of problems over time. In other cases, there was no apparent explanation for the diversity of species found in a greenhouse. Pythium can enter and spread throughout a greenhouse through long- or short-distance transport of infected cuttings and

Table 3. Linear contrasts for effects of Pythium species or mefenoxam resistance on isolate aggressiveness on poinsettia, petunia, and Gerbera daisy

\begin{tabular}{|c|c|c|c|c|}
\hline & Root rot rating ${ }^{x}$ & Above-ground symptom ratingy & Plant height $\mathrm{cm}^{\mathrm{z}}$ (trial 1) & Plant height $\mathrm{cm}^{\mathrm{z}}$ (trial 2) \\
\hline Contrast $^{\mathrm{w}}$ & \multicolumn{4}{|c|}{$\begin{array}{c}\text { Estimate } \pm \text { s.e. } \\
P>|\mathrm{t}|\end{array}$} \\
\hline \multirow{2}{*}{ P. aphanidermatum versus $P$. irregulare } & $0.5 \pm 0.12$ & $0.5 \pm 0.13$ & $-2.8 \pm 1.35$ & $-14.2 \pm 2.54$ \\
\hline & 0.0008 & 0.0022 & 0.0482 & $<0.0001$ \\
\hline \multirow[t]{2}{*}{ Mefenoxam sensitive versus resistant } & $0.1 \pm 0.12$ & $0.1 \pm 0.13$ & $-2.5 \pm 1.35$ & $0.5 \pm 2.54$ \\
\hline & 0.2770 & 0.3651 & 0.0712 & 0.8388 \\
\hline
\end{tabular}

${ }^{w}$ Data were analyzed using PROC GLIMMIX in SAS (Version 9.3); single-degree-of-freedom linear contrasts between groups.

${ }^{x}$ Rating scale with $1=$ healthy white roots and 5 = brown, dead roots; higher root rot ratings correspond to more disease symptoms. Data were combined across two trials before analysis.

${ }^{\mathrm{y}}$ Rating scale with $1=$ healthy plant and $5=$ dead plant; higher ratings correspond to more disease symptoms. Data were combined across two trials before analysis.

${ }^{\mathrm{z}}$ Difference between initial plant height and final plant height on poinsettia. Data are presented separately for trial 1 and trial 2 due to trial $\times$ isolate interactions.

Table 4. Root rot ratings on petunia, Gerbera daisy, and poinsettia inoculated with mefenoxam sensitive and resistant isolates of Pythium aphanidermatum and P. irregulare in the greenhouse

\begin{tabular}{|c|c|c|c|c|c|}
\hline Species & Isolate $^{w}$ & Petunia $^{\mathbf{x}, \mathbf{y}}$ & Poinsettia & Gerbera & Isolate mean \\
\hline P. aphanidermatum & PAS1 & $1.9 \mathrm{ab}$ & $3.9 \mathrm{ab}$ & $2.5 \mathrm{a}$ & 2.8 \\
\hline P. aphanidermatum & PAS2 & $1.9 \mathrm{ab}$ & $4.1 \mathrm{a}$ & $1.8 \mathrm{ab}$ & 2.6 \\
\hline P. aphanidermatum & PAS3 & $2.3 \mathrm{ab}$ & $3.6 \mathrm{abc}$ & $2.3 \mathrm{ab}$ & 2.7 \\
\hline P. aphanidermatum & PAR4 & $1.6 \mathrm{ab}$ & $3.4 \mathrm{abc}$ & $2.3 \mathrm{ab}$ & 2.4 \\
\hline P. aphanidermatum & PAR5 & $1.8 \mathrm{ab}$ & $3.0 \mathrm{abcd}$ & $2.0 \mathrm{ab}$ & 2.3 \\
\hline P. aphanidermatum & PAR6 & $2.4 \mathrm{a}$ & $3.1 \mathrm{abc}$ & $1.8 \mathrm{ab}$ & 2.4 \\
\hline P. aphanidermatum mean & & 2.0 & 3.5 & 2.1 & 2.5 \\
\hline P. irregulare & PIS7 & $1.8 \mathrm{ab}$ & $2.1 \mathrm{~cd}$ & $2.1 \mathrm{ab}$ & 2.0 \\
\hline P. irregulare & PIS8 & $1.8 \mathrm{ab}$ & $2.4 \mathrm{bcd}$ & $2.1 \mathrm{ab}$ & 2.1 \\
\hline P. irregulare & PIS9 & $1.5 \mathrm{ab}$ & $2.1 \mathrm{~cd}$ & $1.9 \mathrm{ab}$ & 1.8 \\
\hline P. irregulare & PIR10 & $1.4 \mathrm{ab}$ & $2.6 \mathrm{abcd}$ & $1.8 \mathrm{ab}$ & 1.9 \\
\hline P. irregulare & PIR11 & $1.3 \mathrm{ab}$ & $2.4 \mathrm{bcd}$ & $2.1 \mathrm{ab}$ & 1.9 \\
\hline P. irregulare & PIR12 & $1.6 \mathrm{ab}$ & $2.5 \mathrm{abcd}$ & $2.5 \mathrm{a}$ & 2.2 \\
\hline$P$. irregulare mean & & 1.6 & 2.4 & 2.1 & 2.0 \\
\hline Noninoculated Control & NEG & $1.0 \mathrm{~b}$ & $1.4 \mathrm{~d}$ & $1.0 \mathrm{~b}$ & 1.1 \\
\hline Host mean & & 1.7 & 2.8 & 2.0 & \\
\hline$P>\mathrm{F}^{\mathrm{z}}$ & & 0.0278 & $<0.0001$ & 0.0268 & \\
\hline
\end{tabular}

${ }^{\mathrm{w}}$ Isolate designations PAS $=P$. aphanidermatum sensitive to mefenoxam; PAR $=$ P. aphanidermatum resistant to mefenoxam; PIS $=P$. irregulare sensitive to mefenoxam; PIR $=$ P. irregulare resistant to mefenoxam.

x Data from two trials were combined and analyzed using PROC GLIMMIX in SAS (Version 9.3); least squares means shown with Tukey-Kramer grouping $($ alpha $=0.05)$ within host type.

${ }^{y}$ Rating scale $1-5$ with $1=$ healthy white roots and $5=$ brown, dead roots; higher root rot ratings correspond to more disease symptoms.

${ }^{\mathrm{z}}$ Isolate effect within host. Differences within a column are indicated by lower case letters. 
transplants, through contaminated irrigation water and media, and can even be spread by certain insects (El-Hamalawi 2008; Hong and Moorman 2005; Hyder et al. 2009; Sanogo and Moorman 1993).

Previous studies identified $P$. aphanidermatum and $P$. irregulare as being responsible for the majority of Pythium root rot cases submitted to clinics in Pennsylvania (Moorman et al. 2002). However, it is uncertain whether clinic samples are representative of problems in the target host population. Species that cause minor disease symptoms may be underrepresented in clinic samples since specimens submitted for diagnosis usually are selected by the client based on existing severe disease symptoms. All greenhouse samples submitted to the PDIC at NC State University are routinely cultured to detect Pythium spp., which may help to address selection bias. However, the implications of a sample testing positive for Pythium at the genus level are unclear if species or isolates differ in aggressiveness on different host species or in their sensitivity to commonly used fungicides. In order to address this issue, our collection consisted of both clinic samples and isolates collected through sampling from a diverse group of greenhouses and plant species.

$P$. irregulare, $P$. aphanidermatum, and $P$. myriotylum were the most commonly isolated species from greenhouse floriculture crops in NC. $P$. aphanidermatum was strongly associated with poinsettia and $P$. myriotylum with garden chrysanthemums. The association of $P$. aphanidermatum and poinsettia is especially interesting due to the nature of the poinsettia production system. In this study, all of the poinsettia producers propagated cuttings in-house, which limited the opportunity for new isolates to enter the greenhouse on cuttings from outside sources. Similar studies have also found a strong association of $P$. aphanidermatum with poinsettia in Pennsylvania (Moorman et al. 2002). It is not known whether the isolates of $P$. aphanidermatum obtained from poinsettia were specifically adapted to poinsettia or if poinsettia production practices favor infection by $P$. aphanidermatum and subsequent symptom development. Growth and infection of $P$. aphanidermatum are favored by warm temperatures (Littrell and McCarter 1970) and poinsettia is propagated in summer when greenhouse temperatures are high. In our trials, symptoms were more severe in trial 1 , which was conducted under hot conditions in July, as compared with trial 2, conducted under cooler temperatures in December. Isolates of $P$. aphanidermatum originally collected from poinsettia infected and caused mild root and shoot symptoms on Gerbera daisy and petunia, indicating that this species is pathogenic on both hosts. However, we did not isolate P. aphanidermatum from any samples of Gerbera daisy or petunia collected during the greenhouse survey. Thus, the reason for the strong association of $P$. aphanidermatum with poinsettia in our samples remains unresolved.

P. irregulare was the most frequently collected species in our survey, comprising approximately $39 \%$ of the isolates obtained. In the

Table 5. Linear contrasts for effects within host of Pythium species or mefenoxam resistance on isolate aggressiveness on poinsettia, petunia, and Gerbera daisy

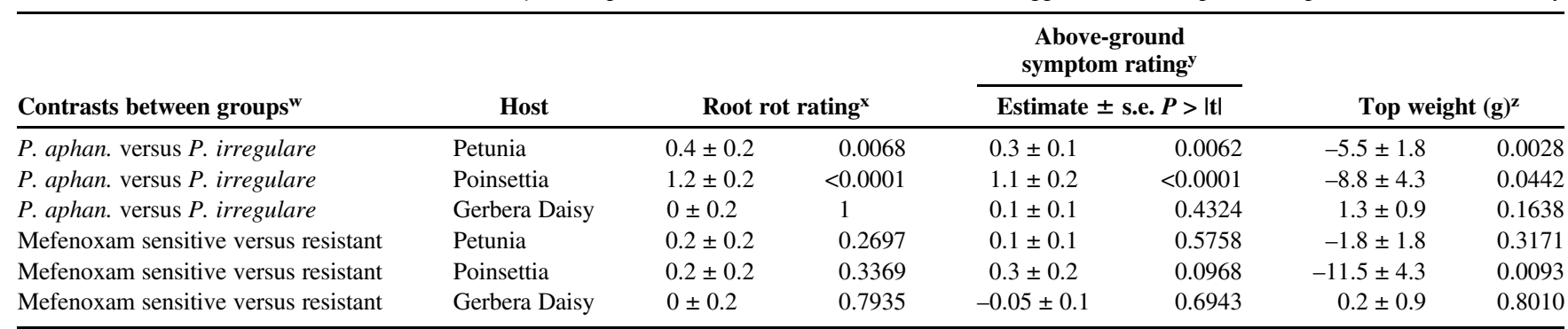

${ }^{\mathrm{w}}$ Data from two trials was combined and analyzed using PROC GLIMMIX in SAS (Version 9.3); single-degree-of-freedom linear contrasts between groups.

${ }^{x}$ Rating scale $1-5$ with $1=$ healthy white roots and $5=$ brown, dead roots; higher root rot ratings correspond to more disease symptoms.

y Rating scale $1-5$ with $1=$ healthy plant and $5=$ dead plant; higher above-ground symptom ratings correspond to more disease symptoms.

${ }^{\mathrm{z}}$ Top weight measurements taken at the end of the trial.

Table 6. Above-ground symptom ratings on petunia, Gerbera daisy, and poinsettia inoculated with mefenoxam sensitive and resistant isolates of $P y t h i u m$ aphanidermatum and $P$. irregulare in the greenhouse

\begin{tabular}{|c|c|c|c|c|c|}
\hline Species & Isolate $^{w}$ & Petunia $^{\mathbf{x}, \mathbf{y}}$ & Poinsettia & Gerbera & Isolate mean \\
\hline P. aphanidermatum & PAS1 & $1.4 \mathrm{a}$ & $3.5 \mathrm{a}$ & $1.6 \mathrm{a}$ & 2.2 \\
\hline P. aphanidermatum & PAS2 & $1.1 \mathrm{a}$ & $3.4 \mathrm{ab}$ & $1.4 \mathrm{a}$ & 2.0 \\
\hline P. aphanidermatum & PAS3 & $1.8 \mathrm{a}$ & $3.0 \mathrm{abc}$ & $1.3 \mathrm{a}$ & 2.0 \\
\hline P. aphanidermatum & PAR4 & $1.4 \mathrm{a}$ & $2.8 \mathrm{abc}$ & $1.5 \mathrm{a}$ & 1.9 \\
\hline P. aphanidermatum & PAR5 & $1.0 \mathrm{a}$ & $2.4 \mathrm{abc}$ & $1.3 \mathrm{a}$ & 1.5 \\
\hline P. aphanidermatum & PAR6 & $1.5 \mathrm{a}$ & $2.6 \mathrm{abc}$ & $1.1 \mathrm{a}$ & 1.8 \\
\hline P. aphanidermatum mean & & 1.4 & 3.0 & 1.4 & 2.0 \\
\hline P. irregulare & PIS7 & $1.1 \mathrm{a}$ & $1.6 \mathrm{c}$ & $1.0 \mathrm{a}$ & 1.3 \\
\hline P. irregulare & PIS8 & $1.0 \mathrm{a}$ & $2.1 \mathrm{abc}$ & $1.4 \mathrm{a}$ & 1.5 \\
\hline P. irregulare & PIS9 & $1.0 \mathrm{a}$ & $1.8 \mathrm{bc}$ & $1.1 \mathrm{a}$ & 1.3 \\
\hline P. irregulare & PIR10 & $1.0 \mathrm{a}$ & $1.9 \mathrm{abc}$ & $1.3 \mathrm{a}$ & 1.4 \\
\hline P. irregulare & PIR11 & $1.1 \mathrm{a}$ & $1.6 \mathrm{c}$ & $1.3 \mathrm{a}$ & 1.3 \\
\hline P. irregulare & PIR12 & $1.0 \mathrm{a}$ & $2.1 \mathrm{abc}$ & $1.6 \mathrm{a}$ & 1.6 \\
\hline$P$. irregulare mean & & 1.0 & 1.9 & 1.3 & 1.4 \\
\hline Noninoculated control & NEG & $1.0 \mathrm{a}$ & $1.3 \mathrm{c}$ & $1.1 \mathrm{a}$ & 1.1 \\
\hline Mean & & 1.2 & 2.3 & 1.3 & \\
\hline$P>\mathrm{F}^{\mathrm{Z}}$ & & 0.1115 & $<0.0001$ & 0.3462 & \\
\hline
\end{tabular}

${ }^{\mathrm{w}}$ Isolate designations $\mathrm{PAS}=P$. aphanidermatum sensitive to mefenoxam $; \mathrm{PAR}=P$. aphanidermatum resistant to mefenoxam; $\mathrm{PIS}=P$. irregulare sensitive to mefenoxam; PIR $=$ P. irregulare resistant to mefenoxam.

x Data from two trials was combined and analyzed using PROC GLIMMIX in SAS (Version 9.3); least squares means shown with Tukey-Kramer grouping (alpha $=0.05)$ within host type.

y Rating scale 1 to 5 with $1=$ healthy plant and $5=$ dead plant. Higher above-ground symptom ratings correspond to more disease symptoms.

${ }^{\mathrm{z}}$ Isolate effect within host. Differences within a column are indicated by lowercase letters. 
pathogenicity trials, all isolates of $P$. irregulare, regardless of the original host of isolation (snapdragon, geranium, petunia, and Gerbera daisy), caused slight to mild root rot symptoms on poinsettia, Gerbera daisy, and petunia. In all cases, infection was verified by reisolation of $P$. irregulare from roots. Isolates of $P$. irregulare from Gerbera daisy were collected from plants with severe symptoms including severe root rot, wilting, stem rot, and plant death. However, these dramatic symptoms could not be reproduced on Gerbera daisy in the greenhouse trials. It is likely that cultivars within a species differ in resistance to infection and symptom development and that isolates of $P$. irregulare differ in pathogenicity and aggressiveness (Higginbotham et al. 2004; Zitnick-Anderson and Nelson 2015). It is also possible that specific environmental or cultural factors are required for severe symptom development and disease epidemics to occur. Inoculum levels, inoculum source, plant stage at infection, original site of infection, and type of potting media used could all influence severity of infection and symptom development.

All isolates of $P$. irregulare from petunia were originally collected from plants with subtle stunting symptoms. In the pathogenicity trial, petunia expressed minor root rot symptoms when inoculated with either $P$. aphanidermatum or $P$. irregulare. Above ground symptoms often were not apparent, but top weights were reduced in inoculated compared with noninoculated plants (Table 5). This slight stunting probably would not be perceived as a disease problem by most growers. Other studies have shown that Pythium species were consistently isolated from necrotic as well as apparently healthy roots in many hosts (Funck-Jensen and Hockenhull 1983; Ivors et al. 2008; Mircetich 1971; Stanghellini and Kronland 1986). This could indicate that petunia or other symptomless hosts harbor Pythium in greenhouses.

Mefenoxam resistance was widespread among the isolates obtained from the greenhouses in this study. Mefenoxam-resistant isolates were recovered from locations where growers had experienced a lack of control of Pythium root rot following applications of mefenoxam, but resistant isolates also were found in some greenhouses with no known history of mefenoxam or metalaxyl use. In the case of under-resourced producers, poor record keeping may have been partially to blame. In other instances, it is likely that resistant isolates were introduced on propagative materials, potting mixes, or other materials purchased from outside sources. Studies in Pennsylvania greenhouses reported a lower incidence of resistant isolates, with only $33 \%$ of isolates screened being resistant to mefenoxam as compared with over $50 \%$ in our study (Moorman et al. 2002). In contrast to our study, mefenoxam resistance in Phytophthora isolates collected from horticultural plants and irrigation water showed a relatively low incidence of mefenoxam resistance (Olson et al. 2013). Isolates of $P$. myriotylum collected from three host plant species in five greenhouses were all sensitive to mefenoxam and more than $99 \%$ of isolates collected from garden chrysanthemum were sensitive to mefenoxam. The majority of chrysanthemum growers sampled obtained propagative materials from outside sources. The reason for the lack of mefenoxam resistance in these two groups is unclear. Other studies have reported a lack of resistance in P. myriotylum isolates collected from field-grown peanut and greenhouse crops including Kangaroo Paw and zonal geranium (Moorman et al. 2002; Tsror (Lahkim) et al. 2005; Wheeler et al. 2005). It is possible that production practices associated with chrysanthemums do not favor resistance development or frequent fungicide applications in the propagation stage. Studies to determine sources and pathways of Pythium inoculum in the floriculture industry could lead to better control of Pythium root rot, and could be used as a model for tracing pathways of pathogen introduction in the floriculture industry in general.

With the exception of $P$. aphanidermatum on poinsettia and $P$. myriotylum on garden chrysanthemums, there were no clear associations between hosts, greenhouse locations and particular Pythium species. This suggests that identification of Pythium to genus may not provide sufficient guidance to growers who submit floriculture samples to diagnostic clinics. The presence of two or more species in a particular greenhouse or host plant species makes forming generalizations about Pythium distributions and supplying informative diagnoses and recommendations difficult. Greenhouse producers could obtain additional value from diagnosis of Pythium to species, testing for mefenoxam resistance, or both.

The method used to screen for mefenoxam resistance was simple, reproducible, and rapid, requiring only 48 to $72 \mathrm{~h}$ for results after initial isolations are made. Greenhouse applications of mefenoxam are much less expensive than the current industry alternatives (Terrazole 35\% WP and Truban 30\% WP), which require considerably higher application rates for potting media high in peat and other organic amendments. Higher costs associated with alternative chemicals could account for the industry's continued reliance on mefenoxam to treat diseases caused by oomycetes despite recommendations to rotate fungicides and to discontinue mefenoxam use after resistance is established in a particular greenhouse. Diagnostic clinics or consultants could use the rapid mefenoxam sensitivity assay to provide growers with timely fungicide application recommendations based on their specific Pythium populations, potentially saving them time and money.

It may also be possible to develop relatively rapid screens to differentiate the predominant Pythium species found in the NC floriculture industry. In cases where Pythium is associated with damping-off diseases, identification to genus may be sufficient to develop effective management strategies. In contrast, identification to genus may not offer adequate information when Pythium root rot is diagnosed on mature plants, and further identification and quantification may be required to offer sound management recommendations. Previously, a real-time PCR protocol was developed to characterize predominant species from wheat (Schroeder et al. 2006). Real-time PCR offers several benefits including high sample throughput and increased sensitivity, and requires less specialized knowledge and skill as compared with traditional identification based on morphological characteristics. Developing rapid methods to identify and quantify Pythium species will help researchers understand the epidemiology and ecology of Pythium within a greenhouse as well as how Pythium species move within the industry.

\section{Acknowledgments}

Support for this research was funded by USDA-APHIS. The authors thank Craig Adkins, Mary Helen Ferguson, Amie Newsome, Rick Morris, Carl Matyac, and Amanda Taylor for assistance with sample collection, Dr. Gary Moorman for advice on working with Pythium, and Shawn Butler, Mike Munster, Landis Lacey, and Kala Parker for technical assistance.

\section{Literature Cited}

Abad, Z. G., Shew, H. D., and Lucas, L. T. 1994. Characterization and pathogenicity of species isolated from turfgrass with symptoms of root and crown rot in North Carolina. Phytopathology 84:913-921.

Aegerter, B. J., Greathead, A. S., Pierce, L. E., and Davis, R. M. 2002 Mefenoxam-resistant isolates of Pythium irregulare in an ornamental greenhouse in California. Plant Dis. 86:692.

Al-Sadi, M., Al-Ghaithi, A. G., Al-Balushi, Z. M., and Al-Jabri, A. H. 2012. Analysis of diversity in Pythium aphanidermatum populations from a single greenhouse reveals phenotypic and genotypic changes over 2006 to 2011. Plant Dis. 96:852-858.

Altschul, S. F., Madden, T. L., Schäffer, A. A., Zhang, J., Zhang, Z., Miller, W., and Lipman, D. J. 1997. Gapped BLAST and PSI-BLAST: A new generation of protein database search programs. Nucleic Acids Res. 25:3389-3402.

Broders, K. D., Lipps, P. E., Paul, P. A., and Dorrance, A. E. 2007. Characterization of Pythium spp. associated with corn and soybean seed and seedling disease in Ohio. Plant Dis. 91:727-735.

Dorrance, A. E., Berry, S. A., Bowen, P., and Lipps, P. E. 2004. Characterization of Pythium spp. from three Ohio fields for pathogenicity on corn and soybean and metalaxyl sensitivity. Online. Plant Heath Progress, doi:10.1094/PHP-2004-0202-01-RS

El-Hamalawi, Z. A. 2008. Acquisition, retention and dispersal of soilborne plan pathogenic fungi by fungus gnats and moth flies. Ann. Appl. Biol. 153:195-203.

Funck-Jensen, D., and Hockenhull, J. 1983. The influence of some factors on the severity of Pythium root rot of lettuce in soil-less (hydroponic) growing systems. Acta Hortic. 133:129-136.

Garzon, C. D., Molineros, J. E., Yanes, J. M., Flores, F. J., Jimenez-Gasco, M. M., and Moorman, G. W. 2011. Sublethal doses of mefenoxam enhance Pythium damping-off of geranium. Plant Dis. 95:1233-1238.

Higginbotham, R. W., Paulitz, T. C., and Kidwell, K. K. 2004. Virulence of Pythium species isolated from wheat fields in eastern Washington. Plant Dis. 88:1021-1026. 
Holmes, K. A., and Benson, D. M. 1994. Evaluation of Phytophthora parasitica var. nicotianae as a biocontrol for Phytophthora parasitica on Catharanthus roseus. Plant Dis. 78:193-199.

Hong, C. X., and Moorman, G. W. 2005. Plant pathogens in irrigation water: challenges and opportunities. Crit. Rev. Plant Sci. 24:189-208.

Hyder, N., Coffey, M. D., and Stanghellini, M. E. 2009. Viability of oomycete propagules following ingestion and excretion by fungus gnats, shore flies, and snails. Plant Dis. 93:720-726.

Ivors, K. L., Abad, Z. G., and Benson, D. M. 2008. Evaluating the pathogenicity of Pythium vexans isolates from Fraser fir in North Carolina. Online. Plant Heath Progress, doi:10.1094/PHP-2008-1006-01-RS

Jeffers, S. N., and Martin, S. B. 1986. Comparison of two media selective for Phytophthora and Pythium species. Plant Dis. 70:1038-1043.

Lévesque, C. A., and de Cock, A. W. A. M. 2004. Molecular phylogeny and taxonomy of the genus Pythium. Mycol. Res. 108:1363-1383.

Littrell, R. H., and McCarter, S. M. 1970. Effect of soil temperature on virulence of Pythium aphanidermatum and Pythium myriotylum to rye and tomato. Phytopathology 60:704-707.

Martin, F. N., and Loper, J. E. 1999. Soilborne plant diseases caused by Pythium spp: Ecology, epidemiology, and prospects for biological control. Crit. Rev. Plant Sci. 18:111-181

Mircetich, S. M. 1971. The role of Pythium in feeder roots of diseased and symptomless peach trees and in orchard soils in peach tree decline. Phytopathology 61:357-360.

Moorman, G. W., Kang, S., Geiser, D. M., and Kim, S. H. 2002. Identification and characterization of Pythium species associated with greenhouse floral crops in Pennsylvania. Plant Dis. 86:1227-1231.

Moorman, G. W., and Kim, S. H. 2004. Species of Pythium from greenhouses in Pennsylvania exhibit resistance to propamocarb and mefenoxam. Plant Dis. 88:630-632.

NCDA. 2012 Floriculture Summary News Release. North Carolina Department of Agriculture and Consumer Services, Raleigh, NC.

Olson, H. A., Jeffers, S. N., Ivors, K. L., Steddom, K. C., Williams-Woodward, J. L., Mmbaga, M. T., Benson, D. M., and Hong, C. X. 2013. Diversity and mefenoxam sensitivity of Phytophthora spp. associated with the ornamental horticulture industry in the southeastern United States. Plant Dis. 97:86-92.
Sanders, P. L. 1984. Failure of metalaxyl to control Pythium blight on turfgrass in Pennsylvania. Plant Dis. 68:776-777.

Sanogo, S., and Moorman, G. W. 1993. Transmission and control of Pythium aphanidermatum in an ebb-and-flow subirrigation system. Plant Dis. 77: 287-290.

Schroeder, K. L., Martin, F. N., de Cock, A. W. A. M., Lévesque, C. A., Spies, C. F. J., Okubara, P. A., and Paulitz, T. C. 2013. Molecular detection and quantification of Pythium species: Evolving taxonomy, new tools and challenges. Plant Dis. 97:4-20.

Schroeder, K. L., Okubara, P. A., Tambong, J. T., Lévesque, C. A., and Paulitz, T. C. 2006. Identification and quantification of pathogenic Pythium spp. from soils in eastern Washington using real-time polymerase chain reaction. Phytopathology 96:637-647

Stanghellini, M. E., and Kronland, W. C. 1986. Yield loss in hydroponically grown lettuce attributed to subclinical infection by feeder rootlets by Pythium dissotocum. Plant Dis. 70:1053-1056.

Tsror (Lahkim), L., Hazanovsky, S., Mordechai-Lebiush, S., Ben-David, T., Dori, I., and Matan, E. 2005. Control of root rot and wilt caused by Pythium myriotylum in Kangaroo Paw (Anigozanthos). J. Phytopathol. 153:150-154.

Uzuhashi, S., Tojo, M., and Kakishima, M. 2010. Phylogeny of the genus Pythium and description of new genera. Mycoscience 51:337-365

van der Plaats-Niterick, A. J. 1981. Monograph of the genus Pythium. Stud. Mycol. 21:1-242.

Wheeler, T. A., Howell, C. R., Cotton, J., and Porter, D. 2005. Pythium species associated with pod rot on West Texas peanuts and in vitro sensitivity of isolates to mefenoxam and azoxystrobin. Peanut Sci. 32:9-13.

White, T. J., Bruns, T., Lee, S., and Taylor, J. 1990 Amplification and direct sequencing of fungal ribosomal RNA genes for phylogenetics. Pages 315 322 in: PCR Protocols: A Guide to Methods and Applications. M. A. Innis, D. H. Gelfand, J. J. Sninsky, and T. J. White, eds. Academic Press, San Diego, CA

Zhang, B. Q., and Yang, X. B. 2000. Pathogenicity of Pythium populations from corn soybean rotation fields. Plant Dis. 84:94-99.

Zitnick-Anderson, K. K., and Nelson, B. D., Jr. 2015. Identification and pathogenicity of Pythium on soybean in North Dakota. Plant Dis. 99:31-38. 